\title{
Water-balance response of Rhinella arenarum (Hensel, 1867) tadpoles to graduated increase in environmental osmolarity
}

\author{
Ferrari, L. ${ }^{\mathrm{a}, \mathrm{b} *}$, de la Torre, FR. ${ }^{\mathrm{a}, \mathrm{c}}$ and Salibián, A. ${ }^{\mathrm{a}, \mathrm{b}}$ \\ ${ }^{a}$ Applied Ecophysiology Program, Basic Sciences Department, National University of Luján, \\ Casilla de Correo 221, (B6700ZBA), Luján, Argentina

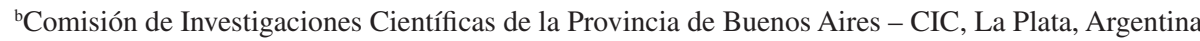 \\ ${ }^{\mathrm{c}}$ Consejo Nacional de Investigaciones Científicas y Técnicas - CONICET, Argentina \\ *e-mail: salibian@mail.unlu.edu.ar
}

Received August 12, 2008 - Accepted November 25, 2008 - Distributed February 28, 2010

(With 4 figures)

\begin{abstract}
The water balance and the upper limit of osmotic tolerance of premetamorphic Rhinella arenarum larvae (Gosner's stage 26) was evaluated after semistatic incubation in electrolyte $(\mathrm{NaCl})$ and non-electrolyte (mannitol) media following a protocol of progressively increased osmotic pressure. Wet and dry weights were measured to calculate the water content as a derived variable indicative of the hydric balance. Statistical analysis was performed using univariate and integrated multivariate analysis. Tadpoles survived in electrolyte and non-electrolyte solutions up to $200 \mathrm{mOsm}$. The discriminant function was the best tool to describe the responses of the animals to external environmental stress under experimental conditions. The results were compared with those obtained in previous studies using a protocol of acute exposure to the same media used in this study. It was concluded that a) multivariate analysis is an appropriate approach to describe the responses of tadpoles to changes in the environmental physicochemical parameters, and b) progressive and acute acclimation to the experimental solutions induced similar responses.
\end{abstract}

Keywords: Rhinella arenarum (synonym of Bufo arenarum), environmental osmotic stress, integrated water balance, young tadpoles, graduated exposure.

\section{Resposta de Rhinella arenarum larvae a meio electrolítico e não electrolítico com aumento escalonado da osmolaridade}

\section{Resumo}

Avaliou-se o balanço hídrico e o limite superior de tolerância osmótica em larvas pré-metamórficas do Rhinella arenarum (etapa 26 de Gosner) sob condições de incubação semiestáticas, num meio eletrolítico $(\mathrm{NaCl})$ e não eletrolítico (manitol), seguindo um protocolo de aumento progressivo da pressão osmótica do meio. A quantificação das respostas se efetuou por meio da medição dos valores de peso úmido e seco e do cálculo, a partir destes, do conteúdo de água, como variável derivada indicativa do equilíbrio hídrico. A análise estatística foi realizada usando análise univariada e multivariada. As larvas conseguiram sobreviver em soluções eletrolíticas e não eletrolíticas até 200 mOsm. A função discriminante foi a melhor ferramenta para descrever as respostas dos animais ao estresse osmótico ambiental. Os resultados foram comparados com os obtidos em estudos anteriores, usando um protocolo de exposição aguda aos mesmos meios de incubação usados neste estudo. Concluiu-se: a) a análise multivariada é a aproximação adequada para descrever as respostas das larvas às mudanças nos parâmetros físico-químicos do seu meio; e b) tanto a aclimatação progressiva, como as exposições agudas às soluções experimentais induziram as respostas semelhantes.

Palavras-chave: Rhinella arenarum (sin. Bufo arenarum), estresse osmótico ambiental, balanço hídrico integrado, larvas novas, exposição progressiva.

\section{Introduction}

Although amphibians are among the most sensitive anamniotes to changes in the external medium, they were able to colonise a wide range of habitats in different environments (Duellman and Trueb, 1994). Most amphibians develop in freshwater and face the risk of exposure to extreme osmotic variations in the external environment, which results in either the dilution or concentration of their milieu interieur. The high water permeability of the skin makes them more vulnerable to environmental osmotic stress than other groups (Boutilier 
et al., 1992; Shoemaker, 1992). Thus, both the salinity of the external medium and the capacity of amphibians to overcome water stress secondary to dehydrating conditions, become critical factors of natural selection, especially during the early larval stages in which the physiological mechanisms are not fully developed and may affect their fitness in terms of survival, development and growth rate (Burggren, 2005). In tadpoles, tolerance to extreme osmolarity conditions is asymmetrical; they can survive in diluted media or even in distilled water for long periods of time (Salibián, 1977; Zamorano and Salibián, 1994), whereas their tolerance to concentrated electrolyte solutions is near the osmotic pressure limit of the extracellular medium (Schrock and Hanke, 1979) by means of adaptive adjustment mechanisms (Balinsky, 1981; Gasser and Miller, 1986; Padhye and Ghate, 1992; Warburg and Rosenberg, 1990).

Rhinella arenarum is widely distributed in Argentina, Uruguay, Bolivia and the south of Brazil (Frost et al., 2006). It is found in arid and humid regions and occurs in habitats as diverse as low forests, steppes and grasslands (Cei, 1980; 1987; Lavilla and Cei, 2001; Williams, 1991), suggesting a remarkable physiological plasticity. In previous papers we have shown that the acute transfer of $R$. arenarum tadpoles (Gosner stage 26) into solutions of different osmolarities has no effect on their survival rate within a wide range, from distilled water to 204 mOsm (Ferrari et al., 1995; Ferrari, 1997). In another series of experiments (Ferrari, 1998), it was found that the mortality rate augmented as the osmotic pressure of the incubation media increased; the 96 hours mean lethal osmolarity ranged between 228.7 and 235.3 mOsm regardless of the type of solute in the external solution and the density of organisms in the incubation media. The integrated analysis of the results indicated that larval responses and the measured water balance parameters differed according to the chemical composition of the incubation medium, i.e. electrolyte or non-electrolyte, suggesting the existence of different compensatory mechanisms probably linked to the presence or absence of $\mathrm{Na}^{+}$ in the media (Ferrari, 1997). In an attempt to complete those studies, the objective of the research presented here was to investigate if the tolerance range of anuran larvae to osmotic stress may be expanded by a treatment of graduated increase in osmolarity.

\section{Materials and Methods}

\subsection{Animal breeding}

The test organisms were obtained by in vitro oocyte fertilisation. Embryos were incubated in 10\% Holtfreter's solution (Hamburger, 1969). At the developmental stage 25 (Gosner, 1960), animals were transferred to artificial pond water (APW) of $5 \mathrm{mOsm}$ of the following composition (in $\mathrm{mM}$ ): $\mathrm{NaCl}, 1.3 ; \mathrm{CaCl}_{2}, 0.8 ; \mathrm{KCl}, 0.1$ and $\mathrm{NaCO}_{3} \mathrm{H}, 0.2$. Tadpoles were kept at laboratory temperature $\left(18-22{ }^{\circ} \mathrm{C}\right)$ and fed daily, ad libitum, with ground commercial fish food; APW was renewed daily. The assays were performed with tadpoles at stage 26 (Gosner, 1960).

\subsection{Experimental design}

The experimental protocol is shown in Figure 1. Prior to the beginning of the experiment, tadpoles were

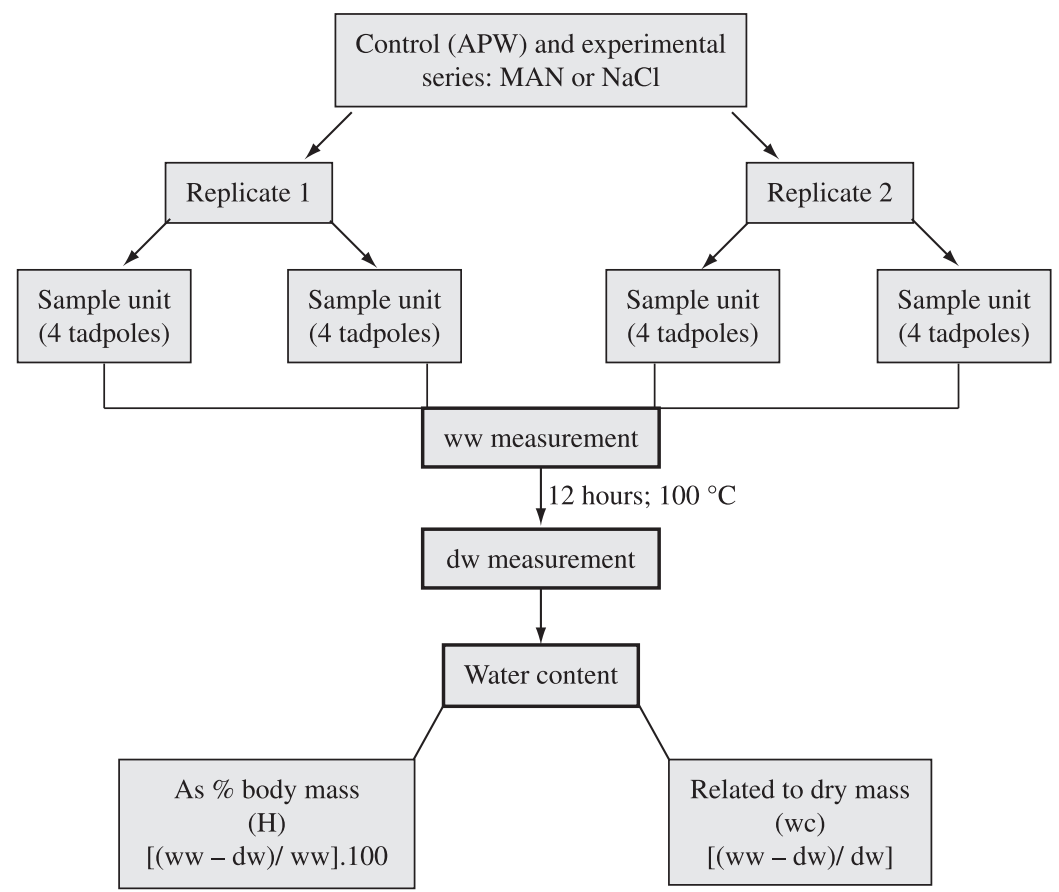

Figure 1. Flow sampling diagram. APW artificial pond water; $\mathrm{MAN}=\mathrm{D}$-mannitol solutions; $\mathrm{NaCl}$ solutions. ww: wet weight (mg); dw: dry weight (mg); wc: water content ( $\left.\mathrm{mg} \mathrm{H}_{2} \mathrm{O} / \mathrm{mg} \mathrm{dw}\right)$; $\mathrm{H}$ : water content $(\%)$. 
accommodated in glass containers and acclimated for 48 hours in APW, in an incubation chamber at $20 \pm 1{ }^{\circ} \mathrm{C}$ and a 12/12 hours light/dark photoperiod. Three series with one hundred tadpoles each were run in duplicate [controls (APW), electrolyte $(\mathrm{NaCl})$ and non-electrolyte solutions (D-mannitol; MAN)], and incubated for 120 hours. The sequence of graduated exposure of larvae to these solutions with increasing osmolarity is presented in Table 1. Osmolarities were checked with a Fiske osmometer. Animals were placed in covered containers to minimise evaporative water loss. During the experiments, animals were kept unfed and maintained under the same temperature and photoperiod conditions of the acclimation period. Incubation media were changed daily. A ratio of 1 tadpole per $4 \mathrm{~mL}$ was kept constant throughout the experiment, (see Ferrari, 1998).

\subsection{Animal sampling}

Two sets of four tadpoles each (sampling unit) were randomly selected from each replicate at 24 hours intervals. One sample representative of the initial condition (APW $5 \mathrm{mOsm}$ ) was taken at the end of the acclimation period. Each sampling unit was treated with MS22 (1:5000) and thoroughly washed with distilled water during 1 minutes to remove solutes from the surface of the animals. These were subsequently transferred into small aluminium caps; the water was drained out and each unit was weighted (ww). After drying at $100{ }^{\circ} \mathrm{C}$ for at least 12 hours, the dry weight (dw) of each sample unit was measured (accuracy $\pm 0.01 \mathrm{mg}$ ). The water content, considered as a derived variable indicative of the hydric balance, was calculated from the wet and dry weights and expressed as mg $\mathrm{H}_{2} \mathrm{O} \cdot \mathrm{mg}^{-1} \mathrm{dw}$ (wc) and as percentage of body mass (H) (Brown et al., 1986). These two expressions are slightly different: wc is an absolute value that allows comparisons within a particular group, while $\mathrm{H}$ is a relative value that allows comparisons between different groups.

\subsection{Statistical analysis}

The transfer from 247 to 271 mOsm (between 96 and 120 hours) had a lethal effect on tadpoles and therefore the analysis was performed with data obtained until 96 hours after exposure (up to $247 \mathrm{mOsm}$ ). Each sampling unit was treated as a unique individual (Figure 1). Significant differences between treatments (control, electrolyte and non electrolyte) were determined for each

Table 1. Temporal sequence of larval exposure to $\mathrm{NaCl}$ and mannitol (MAN) solutions of increasing osmolarity.

\begin{tabular}{cccc}
\hline $\begin{array}{c}\text { Exposure time } \\
\text { (hours) }\end{array}$ & $\begin{array}{c}\text { Osmolarity } \\
(\mathbf{m O s m})\end{array}$ & $\begin{array}{c}\text { NaCl } \\
\left(\text { g.L }^{-1}\right)\end{array}$ & $\begin{array}{c}\text { MAN } \\
(\text { g.L }\end{array}$ \\
\hline $0-24$ & 70 & 2.13 & 12.75 \\
$24-48$ & 141 & 4.27 & 25.50 \\
$48-72$ & 204 & 6.41 & 36.07 \\
$72-96$ & 247 & 7.48 & 43.72 \\
$96-120$ & 271 & 8.54 & 47.92 \\
\hline
\end{tabular}

variable (ww, dw, wc and $\mathrm{H}$ ) using one-way ANOVA followed by Tukey's test. The covariation over time was included, to analyse the effect of treatments on each variable, The Shapiro-Wilk test and the Levene median test were used to assess normality and homogeneity of variance of data, respectively (Zar, 1999). Statistical analyses were performed using the Infostat software.

A canonical discriminant analysis (CDA, Hair et al, 1995) was used to evaluate the integrated response of larvae to osmotic stress and to compare it with that obtained in previous studies under acute exposure conditions. It was conducted using the BMDP package. For all tests, the null hypothesis was rejected when $\mathrm{p}<0.05$.

\section{Results}

The mean \pm ESM of ww, dw, wc and $\mathrm{H}$ obtained for each experimental condition up to 96 hours of exposure and the results of the corresponding Tukey comparisons are shown in Figure 2. Statistically significant differences over time were observed for ww and dw in both control and experimental media (Figure $2 \mathrm{a}$ and $\mathrm{b}$ ). This response in APW can be explained by the significant decline in ww and dw, particularly at the end of the assay period and could be due to the fasting condition of the animals. Although a significantly decreasing trend in ww with increasing osmolarity and time of exposure was observed for both the control and the experimental media, the response of this variable differed among them.

Dry weight showed a biphasic response: an increase above a concentration of 204 mOsm (48-72 hours of exposure time) in $\mathrm{NaCl}$ and $\mathrm{MAN}$, with no significant differences between treatments. On the contrary, the response of the derived parameters (wc and $\mathrm{H}$ ) remained stable in the control (APW-5mOsm) throughout the test and differed significantly from the two experimental media, which, in turn, differed between themselves (Figure 2c and d). A significant decrease was observed in

Table 2. Canonical discriminant analysis: evaluation of water balance by means of an integrated response of Rhinella arenarum young tadpoles incubated in a series of MAN and $\mathrm{NaCl}$ solutions of increasing osmolarity.

\begin{tabular}{lrrrrrr}
\hline & \multicolumn{2}{c}{ APW } & \multicolumn{2}{c}{ MAN } & \multicolumn{2}{c}{ NaCl } \\
\hline & CV1 & CV2 & \multicolumn{1}{c}{ CV1 } & CV2 & CV1 & CV2 \\
\hline wW & 0.30 & 0.10 & 0.54 & -0.43 & 0.23 & -0.13 \\
dw & -1.78 & -1.21 & -4.76 & 7.68 & 0.76 & 2.53 \\
wc & -0.28 & -0.24 & -0.14 & -0.95 & -0.20 & -1.07 \\
H & -1.00 & 0.82 & -3.36 & 6.95 & -0.25 & 5.49 \\
VAR & 0.84 & 1.00 & 0.97 & 1.00 & 0.84 & 1.00 \\
\hline
\end{tabular}

APW: artificial pond water; MAN: D- mannitol solutions; $\mathrm{NaCl}$ : $\mathrm{NaCl}$ solutions; $\mathrm{CV} 1$ and $\mathrm{CV} 2$ eigenvectors for first and second canonical variable; VAR: cumulative proportion of the total dispersion. ww: wet weight (mg); dw: dry weight $(\mathrm{mg})$; wc: water content $\left(\mathrm{mg} \mathrm{H}_{2} \mathrm{O} / \mathrm{mg} \mathrm{dw}\right) ; \mathrm{H}$ : water content (\%). 

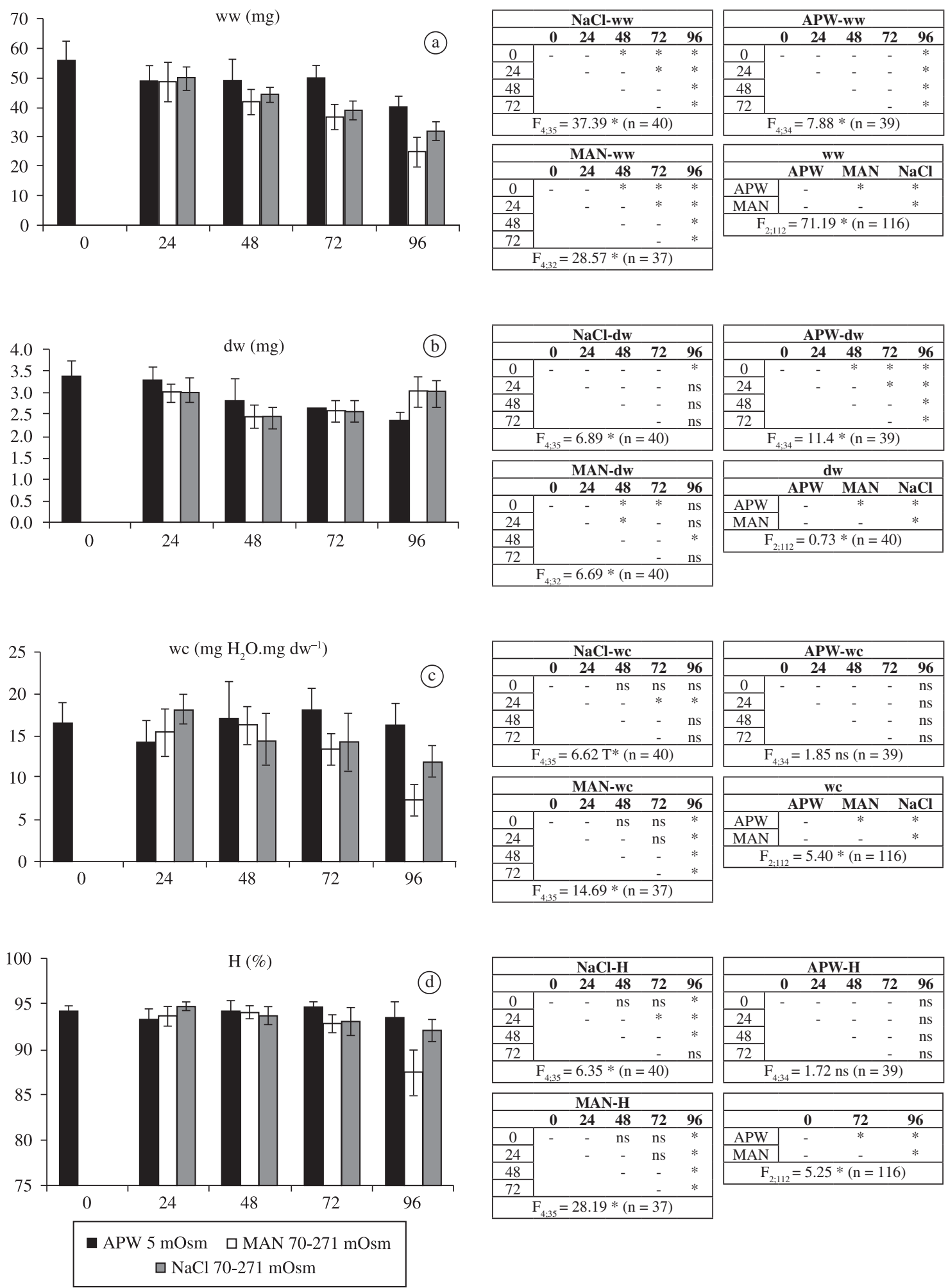

Figure 2. Temporal evolution of mean + ESM of ww (A), dw (B), wc (C) and H (D) in Chaunus arenarum incubated during 96 hours in control (APW), non electrolyte (MAN) and electrolyte $(\mathrm{NaCl})$ media sampling every 24 hours. Fisher's F statistic and the corresponding matrix of Tukey's comparisons are indicated on the right side of each graphic. Statistically significant differences: $*(\mathrm{p}<0.05)$; ns, not significant. 
wc and $\mathrm{H}$ after transfer to $204 \mathrm{mOsm} \mathrm{NaCl}$ (48-72 hours of exposure) and to 247 mOsm MAN (72-96 hours of exposure).

Figure 3 shows the results of the canonical discriminant analysis for each solution, and a diagrammatic representation of results from multiple comparisons. In most cases, $\mathrm{dw}$ was the variable with the highest discriminant capacity (Table 2). In APW controls, the integrated analysis of variables indicated a stable and uniform pattern over time. Larvae incubated in MAN solutions showed a tendency to differ with increasing osmolarity, especially towards the end of the assay. No significant differences were observed between 0 and 24 hours, indicating that larvae tolerated transfer from APW to 70 mOsm MAN, but there were significant differences among the other sampling times/osmolarities.

The integrated response of variables in tadpoles exposed to $\mathrm{NaCl}$ solutions showed a tendency of dispersion in the responses over time. The test of multiple comparisons shown significant differences between cero and 24 hours, suggesting that exposure to an electrolytic solution of $70 \mathrm{mOsm}$ induced larval response; however,
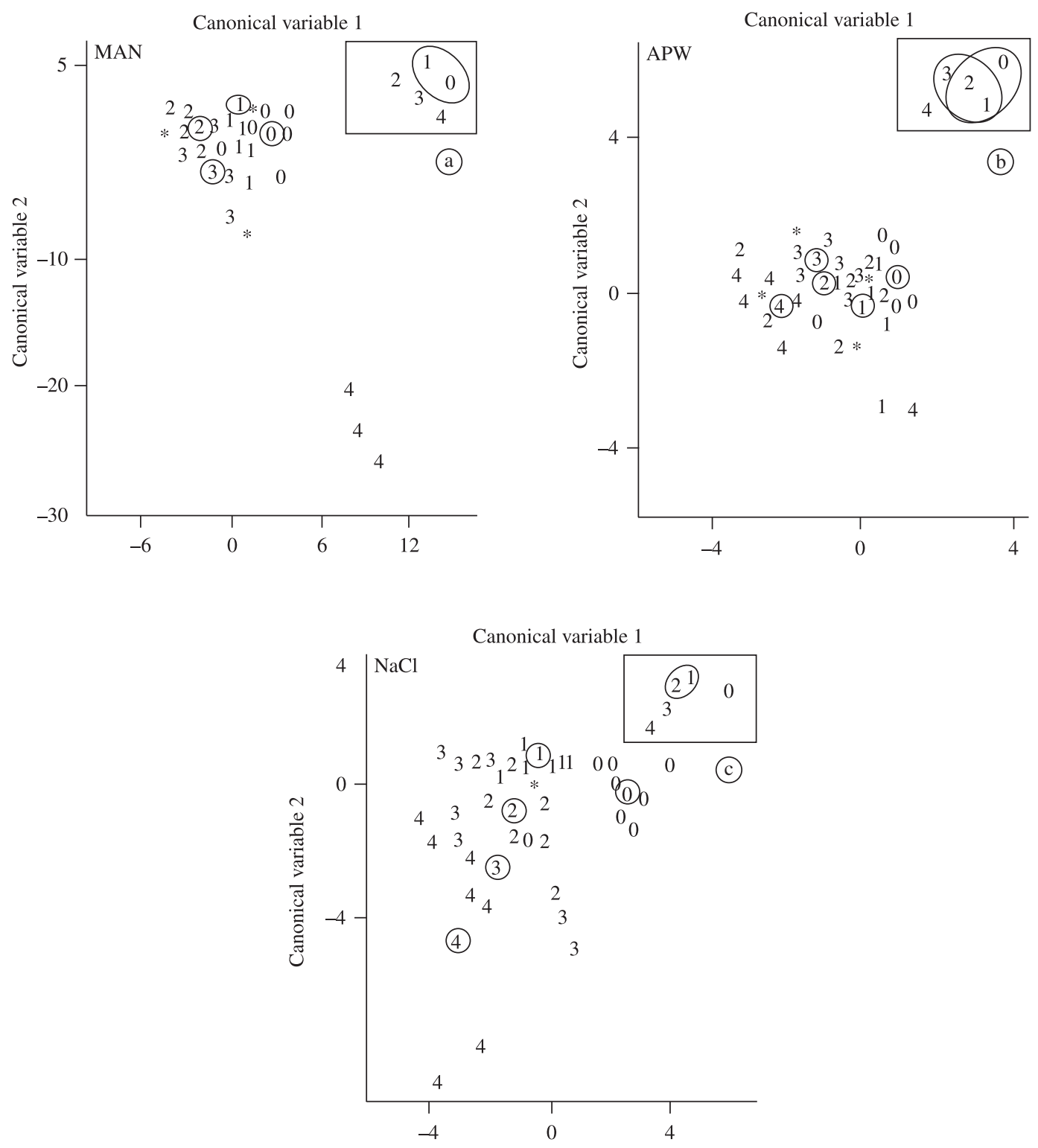

Figure 3. Plot of multiple discriminant analyses in Rhinella arenarum young tadpoles exposed to electrolytic and non electrolytic solutions of increased osmolarity. Numbers indicate relative position of each sampling unit (as all physiological parameters measured). Encircled numbers are mean values for each assayed time. The representation of multiple comparison tests is in the right upper angle where the encircled numbers indicate absence of statistically significant differences. $0=0$ hours; $1=24$ hours; $2=48$ hours; $3=72$ hours; $4=96$ hours. * indicate overlapping values. 
Table 3. Canonical discriminant analysis: evaluation of water balance by means of an integrated response of Rhinella arenarum young tadpoles to all assayed solutions, at each exposure time

\begin{tabular}{lrrrrrrrr}
\hline & \multicolumn{2}{c}{ 24 hours } & \multicolumn{2}{c}{ 48 hours } & \multicolumn{2}{c}{ 72 hours } & \multicolumn{2}{c}{ 96 hours } \\
\hline & CV1 & \multicolumn{1}{c}{ CV2 } & CV1 & CV1 & CV2 & CV2 & CV1 & CV2 \\
\hline wW & 7.93 & -10.86 & 0.72 & 1.26 & 1.26 & 1.21 & 0.49 & 0.01 \\
dw & -5.03 & 8.98 & -8.30 & -20.98 & -15.99 & -20.01 & -5.11 & 2.46 \\
wc & -5.97 & 8.07 & 0.24 & -0.71 & -1.43 & -2.35 & -0.57 & 0.60 \\
H & -4.93 & 7.50 & -5.25 & -3.62 & -3.03 & -2.65 & -0.12 & -0.66 \\
VAR & 0.91 & 1.00 & 0.91 & 1.00 & 0.85 & 1.00 & 0.88 & 1.00 \\
\hline
\end{tabular}

For abbreviations, see Table 2.
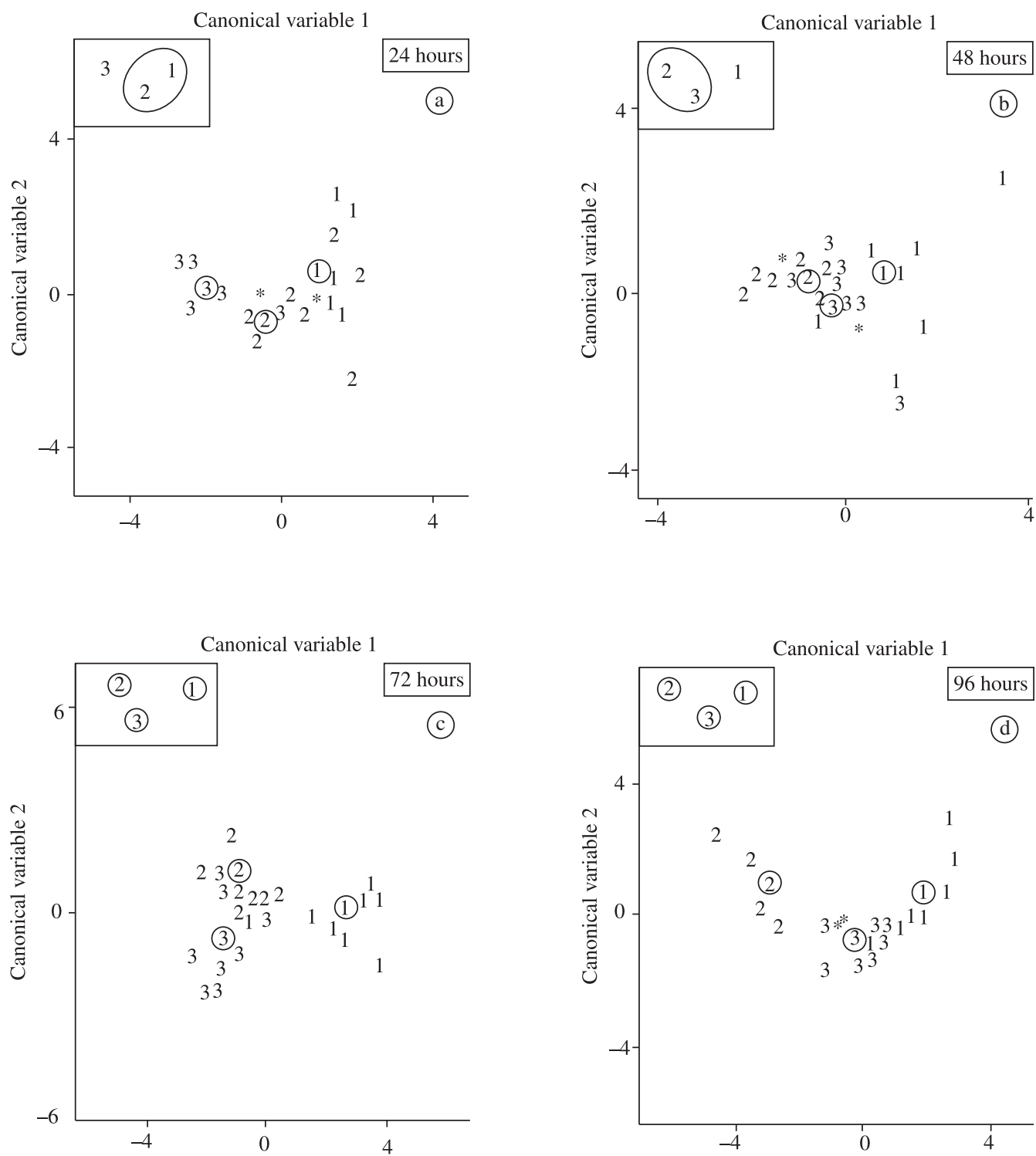

Figure 4. Plot of multiple discriminant analyses for each assayed time in Rhinella arenarum young tadpoles exposed to electrolytic and non electrolytic solutions of increased osmolarity. Numbers indicate relative position of each sampling unit (as all physiological parameters measured). Encircled numbers are mean values for each assayed time. The representation of multiple comparison tests is in the left upper angle where the encircled numbers indicate absence of statistically significant differences. $0=$ APW artificial pond water; $1=\mathrm{D}$-mannitol solutions; $2=\mathrm{NaCl}$ solutions. * indicate overlapping values. 
larvae showed no significant differences between 70 and $141 \mathrm{mOsm}$, and behaved differently when exposed to 204 mOsm.

The CDA for each sampling time and the diagrammatic representation of the results of multiple comparisons are shown in Figure 4. The best discriminant variables were ww for $70 \mathrm{mOsm}$, and dw for higher osmolarities (Table 3).

The integrated behaviour of variables revealed that larvae exposed to $\mathrm{NaCl} 70 \mathrm{mOsm}$ differed from the other two groups and that there were different responses of larvae exposed to concentrations above 204 mOsm between electrolyte or non-electrolyte solutions.

The multiple comparisons test used to analyse the responses of the variables suggested similarity between $\mathrm{NaCl}$ and $\mathrm{MAN}$, which in turn differed from the controls in APW and a transition point at which the regulation of the water balance compromised the stability of dw. Statistically significant differences among the three solutions were found after transfer to 204 mOsm 72 hours later.

\section{Discussion}

In the experiments reported here involving graduated exposure of $R$. arenarum tadpoles to media of increasing osmolarity, animals could withstand an osmolarity as high as $200 \mathrm{mOsm}$; larval mortality was markedly increased 24 hours after transferring them from 204 to $247 \mathrm{mOsm}$, reaching $100 \%$ at $271 \mathrm{mOsm}$. When larvae at the same stage were acutely transferred from APW to $271 \mathrm{mOsm} \mathrm{MAN}$ or $\mathrm{NaCl}$, the mortality rate was approximately 10 and $90 \%$ after 24 and 96 hours, respectively (Ferrari, 1998). Therefore, we conclude that, independent of the two experimental conditions (graduated and acute exposure), the upper limit of osmotic tolerance is somewhere between 200 and $250 \mathrm{mOsm}$. This conclusion is in agreement with the fact that, when anuran tadpoles are exposed to increasing external osmotic stress at osmotic pressures higher than those of their extracellular media (up to $200 \mathrm{mOsm}$ ), they are no longer capable of sustaining an osmotic gradient (Burggren and Just, 1992). However, in natural populations of $R$. arenarum, larval development takes place in environments with a large amount of electrolyte compounds and an osmotic pressure considerably lower than that limit. Thus, the capability of larvae to overcome relatively high osmolarities may reflect a "safety range" at the upper level of their osmotic tolerance range. In regard to the lower limit, it was shown that they are able to tolerate incubation in distilled water (Ferrari et al., 1995). In this context, Gómez-Mestre and Tejedo (2005) suggest that in amphibians there is a link between salinity tolerance during the aquatic phase and tolerance to drought during the terrestrial phase by means an exaptation process.

Tadpoles exposed to non-electrolyte solutions cannot replace lost ions from the exterior and lose water continuously. This may lead to an increase in the concen- tration of plasma ions, which in turn produces a remarkable increase in the plasma osmotic pressure (Schrock and Hanke 1979; Schrock et al, 1980). Thus, it could be assumed that death in MAN and $\mathrm{NaCl}$ solutions above 200 mOsm might result from hypernatremia induced by different pathways according to the nature of the medium.

According to our results, under acute and graduated exposure Rhinella arenarum premetamorphic tadpoles may not be able to adapt to saline environments for long periods of time. However, tadpoles incubated in hypertonic media synthesise additional osmolytes, like urea, for osmotic adjustments. This notion is supported by the presence of arginase, which is a key enzyme of the urea cycle, in early embryonic stages of the same species (Rovedatti et al., 1995); this is observed even before enzyme activity is progressively activated at the end of the larval period. In addition, Castañé et al. (1997) demonstrated that arginase activity was selectively increased in embryos grown in hypoosmotic media, such as distilled water. All these events occur at advanced organogenetic stages during the embryonic-larval transition period, suggesting the presence of osmoregulatory mechanisms at early stages of amphibian development, even when the specific structures are not fully developed.

Tadpoles exposed to $\mathrm{NaCl}$ and $\mathrm{MAN}$ showed a higher decrease in wc as compared with the controls; this effect was more pronounced above $200 \mathrm{mOsm}$ due to a higher increase in dw, particularly in the non-electrolyte medium. Our results indicate that variations in ww and dw and the relationship with each other may account for the relative stability of water content using wc as an index of the water balance. However, $\mathrm{dw}$ is the most influential variable contributing to different responses to osmotic stress. It should be emphasised that, at metamorphosis, body weight is the strongest factor determining the probability of survival and fitness of juveniles (GómezMestre and Tejedo, 2004).

Although the increase in dw may result from the influx of mannitol, which possibly penetrates into the organism through a paracellular way (Fidelman and Watlington, 1987), tadpoles exposed to $\mathrm{MAN}$ and to $\mathrm{NaCl}$ had similar $\mathrm{dw}$ values. The sodium content of larval tissues was found to be significantly higher in tadpoles exposed to $141 \mathrm{mOsm}$ $\mathrm{NaCl}$ for 96 hours than in the APW controls, with the former showing hypernatremia probably due to passive uptake of electrolytes (Ferrari 1995). A similar finding was reported by Gomez-Mestre et al. (2004) for Bufo calamita tadpoles at Gosner's stage 25. On the other hand, the skin of tadpoles of the same species and age immersed for 24 hours in APW, distilled water and $141 \mathrm{mOsm} \mathrm{MAN}$ and $\mathrm{NaCl}$ were morphologically similar, as indicated by scanning electron microscopy (Ferrari and Salibián, 1999).

The fact that tadpoles in 204 mOsm (at 72 hours) differed among all treatments with dw being the variable of highest discriminant capacity (see Figure 4), would indicate that the response of the considered parameters to osmolarity is probably linked to the chemical com- 
position of the media. The integrated response of larvae exposed to osmolarities higher than 200 mOsm for short periods suggests a tendency to a progressive water imbalance until death due to the lack of compensatory mechanisms for maintaining the osmotic pressure of the extracellular fluids within the normal range. This observation is in agreement with the fact that the limit of the extracellular medium for larvae of terrestrial amphibians was set at approximately 200 mOsm (Balinsky, 1981; Burggren and Just, 1992). Within this context it must be considered the possibility - not reported for $R$. arenarum tadpoles - that larvae exposed to media with osmolarity higher than 200 mOsm may drink external solutions as an "emergency response" to a stressful environment.

Our past (Ferrari et al., 1995; Ferrari, 1997; Ferrari, 1998) and present results allow us to conclude that $R$. arenarum young tadpoles cannot withstand osmotic pressures greater than $200 \mathrm{mOsm}$ regardless of the acclimation schedule. The results of this study indicated that among the factors evaluated, $\mathrm{dw}$ had the best discriminant capacity for water balance regulation in tadpoles. Since in this study the different treatments were performed simultaneously, using experimental animals of the same age and body weight, and under constant temperature, our results must be attributed to environmental osmotic stress.

Acknowledgements - The authors wish to thank Prof. Rubén J Lombardo (University of Buenos Aires) for statistical assistance. This research was supported by grants from CONICET, CIC and the National University of Luján, Argentina. All procedures were in compliance with Argentinean regulations on animal welfare.

\section{References}

BALINSKY, JB., 1981. Adaptation of nitrogen metabolism to hyperosmotic environment in Amphibia. Journal of Experimental Zoology, vol. 215, no. 3, p. 335-350.

BOUTILIER, RG., STIFFLER, DF. and TOEWS, DP., 1992. Exchange of respiratory gases, ions, and water in amphibious and aquatic amphibians. In FEDER, ME. and BURGGREN, WW. (Eds.). Environmental Physiology of the Amphibians. Chicago: University of Chicago Press. p. 81-124.

BROWN, SC., HORGAN, EA., SAVAGE, LM. and BROWN, PS., 1986. Changes in body water and plasma constituents during bullfrog development: effects of temperature and hormones. Journal of Experimental Zoology, vol. 237, no. 1, p. 25-33.

BURGGREN, WW. and JUST JJ., 1992. Developmental changes in physiological systems. In FEDER, ME. and BURGGREN, WW. (Eds.). Environmental Physiology of the Amphibians. Chicago: University of Chicago Press. p. 467-530.

BURGGREN, WW., 2005. Developing animals flout prominent assumptions of ecological physiology. Comparative Biochemistry and Physiology: part A, vol. 141, no. 4, p. 430-439.

CASTAÑÉ, PM., ROVEDATTI, MG. and SALIBIÁN, A., 1997. Arginase activity of Bufo arenarum embryos is sensitive to external osmotic pressure. Biological Research, vol. 30, p. $23-26$
CEI, JM., 1980. Amphibians of Argentina: an update. Monitore Zoologico Italiano. N.S. Monografia no. 2, p. 1- 609.

1987. Additional notes to Amphibians of Argentina: a second update, 1980-1986. Monitore Zoologico Italiano. N.S. no 21, p. 209-272.

DUELLMAN, WE. and TRUEB, L., 1994. Biology of Amphibians. London: The Johns Hopkins University Press. p. 1-670.

FERRARI, L., 1995. Equilibrio Hidromineral de larvas de Bufo arenarum: respuestas compensatorias al stress osmótico y al cadmio. Buenos Aires: Facultad de Ciencias Exactas y Naturales. [Tese de Doutorado].

FERRARI, L., LOMBARDO, RJ. and SALIBIÁN, A., 1995. Quantitative evaluation of water balance in Bufo arenarum young tadpoles after acute exposure to D-mannitol solutions: a multivariate approach. Biological Research, vol. 28, p. 251-259.

FERRARI, L., 1997. Quantitative evaluation of water balance in Bufo arenarum young tadpoles after acute exposure to concentrated $\mathrm{NaCl}$ solutions: a multivariate approach. Biological Research, vol. 30, p. 65-73.

1998. Tolerance of high electrolytic and non-electrolytic osmolarities in Bufo arenarum premetamorphic tadpoles under organism density stress. Alytes, vol. 15, no. 4, p. 171-175.

FERRARI, L. and SALIBIÁN, A., 1999. Effect of Cadmium on the epidermic structure of Bufo arenarum tadpoles: influence of the chemical composition of the incubation media. Archives of Physiology and Biochemistry, vol. 107, no. 2, p. 91-96.

FIDELMAN, ML. and WATLINGTON, C., 1987. Effect of aldosterone and insulin on mannitol, $\mathrm{Na}+$ and $\mathrm{Cl}$ - fluxes in cultured epithelia of renal origin (A6): evidence for increased permeability in the paracellular pathway. Biochimica et Biophysica Acta (BBA) - Molecular Cell Research, vol. 931, no. 2, p. 205-214.

FROST, DR., GRANT, T., FAIVOVICH, J., BAIN, RH., HAAS, A., CÉLIO. FB., HADDAD, CFB., SÁ, RO., RAFAEL, O., CHANNING, A., WILKINSON, M., DONNELLAN, SC., RAXWORTHY, CJ., CAMPBELL, JA., BLOTTO, BL., MOLER, P., DREWES, RC., NUSSBAUM, RA., LYNCH, JD., GREEN, DM. and WHEELER, WC., 2006. The amphibian tree of life. Bulletin of the American Museum of Natural History, vol. 297, p. 1-370.

GASSER, KW. and MILLER, BT., 1986. Osmoregulation of larval blotched tiger salamanders, Ambystoma tigrinum melanostictum, in saline environments. Physiological Zoology, vol. 59, no. 1, p. 43-648.

GÓMEZ-MESTRE, I. and TEJEDO, M. 2004. Contrasting patterns of quantitative and neutral genetic variation in locally adapted populations of the natterjack toad. Bufo calamita: Evolution, vol. 58, no. 10, p. 2343-2352.

,2005. Adaptation or exaptation? An experimental test of hypotheses on the origin of salinity tolerance in Bufo calamita. Journal of Evolutionary Biology, vol. 18, no. 4, p. 847-855.

GÓMEZ-MESTRE, I., TEJEDO, M., RAMAYO, E. and ESTEPA, J., 2004. Developmental alterations and osmoregulatory physiology of a larval anuran under osmotic stress. Physiological and Biochemical Zoology, vol. 77, no. 2, p. 267-274. 
GOSNER, KL., 1960. A simplified table for staging anuran embryos and larvae with notes on identification. Herpetologica, vol. 16, p. 183-190.

HAIR, JF., ANDERSON, RE., TATHAM, R.L. and BLACK, WC., 1995. Multivariate data analysis. New Jersey: Prentice Hall. p. 1-707.

HAMBURGER, V., 1969. A manual of experimental embryology. Chicago: University of Chicago Press. p.1-220.

LAVILLA, EO. and CEI, JM., 2001. Amphibians of Argentina: a second update, 1987-2000. Museo Regionale de Scienze Naturali di Torino. Monografia no. 28, p.1 -175.

PADHYE, AD. and GHATE, HV., 1992. Sodium chloride and potassium chloride tolerance of different stages of the frog, Microhyla ornata. Herpetologica Journal, vol. 2, p. 18-23.

ROVEDATTI, MG., CASTAÑÉ, PM. and SALIBIÁN, A., 1995. Arginase activity in Bufo arenarum embryos. Biological Research, vol. 28, p. 173-176.

SALIBIÁN, A., 1977. Transporte de cloro y de sodio a través de la piel in situ de anfibios sudamericanos. Boletín del Museo Nacional de Historia Natural (Chile), vol. 35, p. 121-163.

SHOEMAKER, VH., 1992. Exchange of water, ions, and respiratory gases in terrestrial amphibians. In FEDER, ME. and BURGGREN, WW. (Eds.). Environmental Physiology of the Amphibians. Chicago: University of Chicago Press. p. $125-150$.

SCHRÖCK, H. and HANKE, W., 1979. Cell volume regulation in tadpoles of Xenopus laevis in hypertonic salt solution. Comparative Biochemistry and Physiology, vol. 63A, p. $399-403$.

SCHRÖCK, H., BAUER, O., MERKLE, S. and HANKE, W., 1980. Cell volume regulation in juveniles of Xenopus laevis in hypertonic mannitol solution. Comparative Biochemistry and Physiology, vol. 65A, p. 259-265.

WARBURG, MR. and ROSENBERG, M., 1990. Ion and water balance and their endocrine control in the aquatic amphibians. In HANKE, W. (Ed.). Biology and physiology of amphibians. New York: Gustav Fisher Verlag Stuttgart. p. 385-403.

WILLIAMS, JD., 1991. Anfibios y Reptiles. In: HL. López y EP. Tonni (Eds.). Situación ambiental de la Provincia de Buenos Aires. Recursos y Rasgos Naturales en la Evaluación Ambiental. CIC Buenos Aires, Argentina, vol. 1, no. 4, p. 1-21.

ZAMORANO, B. and SALIBIÁN, A., 1994. Ionic net fluxes through the in situ epithelia of larval Caudiverbera caudiverbera (Anura, Leptodactylidae). Alytes, vol. 12, no. 3, p. 135-144.

ZAR, JH., 1999. Biostatistical analysis. New Jersey: Prentice Hall. p. 1-662 